ISSN : 2580-3220, E-ISSN : 2580-4588

J. Mandiri., Vol. 5, No. 2, Desember 2021 (61 - 76)

(C)2017 Lembaga Kajian Demokrasi

dan Pemberdayaan Masyarakat (LKD-PM)

DOI: https://doi.org/10.33753/mandiri.v5i2.170

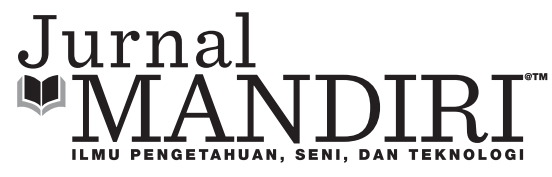

\title{
Improving the Business Performance of Entrepreneurial Students in Pamulang University Through the Digital Business Ecosystem
}

\author{
Adi Martono \\ Fakultas Ekonomi dan Bisnis, Universitas Pamulang \\ dosen01599@unpam.ac.id \\ Mohammad Safí'i \\ Fakultas Ekonomi dan Bisnis, Universitas Pamulang \\ dosen01486@unpam.ac.id
}

\begin{abstract}
Students as an educated community group have a higher success rate in doing business. But they must be good at managing their time between running a business and studying. This research will focus on students who do business and the external factors that influence it. The object of research is students majoring in Accounting and Management, Faculty of Economics, Pamulang University who run a business. This study has several objectives, namely 1. to obtain a profile of these students in running their business. 2. get information on whether the campus environment can encourage their business development. This research is a qualitative research. Researchers used a questionnaire to collect information and data. The questionnaire is distributed online to students who have businesses. From the questionnaire, information was obtained that $47 \%$ of students sold their own products, more than $50 \%$ had been doing business for less than 1 year and more than $60 \%$ were micro entrepreneurs. Students use social media to market their products but they also need digital marketing training, on the other hand they agree that the marketplace can be a means to market products among the Pamulang University academic community. The conclusion is that Pamulang University, which has more than 70,000 students (source pddikti.kemendikbud.go.id), is a large market for students to sell their products and therefore needs to be supported by technology and a business ecosystem so that all of them can connected each others. Campus can cooperate with other parties to utilize technology such as marketplace.
\end{abstract}

Keywords : Student Entrepreneurship, Business Ecosystem, Marketplace

\section{INTRODUCTION}

This research was conducted at the Pamulang University campus, to be precise, the Faculty of Economics, Undergraduate Accounting and Management Study Program. As it is known that some students have businesses and these businesses are run and developed, among others, to finance their studies. Some of them have marketed to their fellow students or friends as their target market. On the other hand, the number of the Pamulang University academic community reaching more than 74,000 people (Kemdikbud, 2021) has not optimally become a market for students in selling their products. Such a large market opportunity has not been managed properly due to various things and this is the theme of this research.

The government realizes the importance of the role of entrepreneurs in developing the national economy because entrepreneurs play a major 
role in absorbing labor, increasing the country's foreign exchange and optimizing the use of natural resources (Isanawikrama, 2019). The Ministry of Cooperatives and SMEs stated that in 2018 there were 64,194,057 MSMEs or $99.99 \%$ of existing businesses and involved 116,978,631 workers or $96.82 \%$ of the entire workforce in the business sector (MSME Data, 2019). The data above shows that entrepreneurs, especially MSMEs, have a vital role in the Indonesian economy.

This study focuses on students who also act as entrepreneurs. Previous research has stated that formal education programs affect several personal characteristics that support entrepreneurship. Formal education has an important role that can affect the entrepreneurial potential of students. Universities can contribute to policy making to develop entrepreneurial potential student (Simanjuntak et al., 2016). One of them is when students take entrepreneurship courses, which are taught at various campuses, providing provisions and understanding of entrepreneurship both conceptually and practically. This is an advantage that is obtained by entrepreneurial students compared to other entrepreneurs.

Entrepreneurial students need to be supported because they have things that become capital for them in running their business. In his research, students have the capital, which includes the courage to take risks, self-motivation, finance and knowledge that become the driving force (Helmi, 2011). On the other hand, entrepreneurial students face several stressors, both because it involves their business and those related to their role as students such as conflicting schedules, skipping college or delayed graduation (Osi Isna Sabela, October 2014). Even so, students have better opportunities to develop their businesses than other community groups, partly because students get entrepreneurship courses on campus (Rahman Faisal, 2020).

Realizing this, the government of the Republic of Indonesia, through various ministries, has organized various programs to encourage the growth of entrepreneurs, especially young entrepreneurs such as students. Several ministries organize various programs to motivate students to becomeentrepreneurship, forexamplethe Ministry of Research and Technology which organizes the Indonesian Student Entrepreneurship Expo program every year on an ongoing basis, which aims to show the creativity of students who are entrepreneurship and become an arena for these students to collaborate and form networks with entrepreneurs. in Indonesia (Info-Iptek-Dikti, 2017), the Ministry of Education through the Free Learning Entrepreneurship 2020 program which aims to cultivate the entrepreneurial spirit and abilities of students in Indonesia so that they can compete with other countries by optimizing national resources (Indonesian Student Entrepreneurship Program, 2020) and also the new Ministry, as is the case with the Entrepreneur Student Movement program (UKM, 2018). In practice, the programs rolled out by the government are not optimal to encourage entrepreneurial students to grow because, among other things, the number of entrepreneurial students who can be involved is still small due to the limited government budget.

On the other hand, students face many challenges besides they have to attend lectures to pursue their dreams of getting an academic degree, they must devote their energy and thoughts so that their business runs smoothly. Their ability to manage these two things will affect their business performance, where the performance is influenced by many factors that influence each other, both internal and external factors. According to Jacson in (Wu, 2009) states, according to systems theory, a business unit is a system that operates in a larger system environment. These systems will interact with each other and change the influencing factors.

The current situation, where the Covid-19 pandemic is taking place, has affected or had an impact on the economy and business in the world as well as in Indonesia. The necessity to carry out physical distancing and the provision for Work from Home for government and private employees, has an impact, among others, is a decrease in people's consumption and purchasing 
power. Another follow-up impact is that business people feel a decline in sales, including businesses run by students. Various problems are faced by business actors, especially Micro, Small and Medium Enterprises (MSMEs). The Ministry of Cooperatives and SMEs said there were around 37,000 MSMEs who reported that their businesses were very seriously affected by the Covid-19 pandemic: around 56\% experienced a decline in sales, $22 \%$ experienced problems related to financing aspects, $15 \%$ experienced problems with distribution of goods, and $4 \%$ have difficulty in obtaining raw materials (Pakpahan, 2020).

Of the many business performances studied by researchers from various parts of the world, this research also focuses on the discussion of marketing performance. Students as entrepreneurs must be observant in seeing the market, especially in the Covid-19 pandemic situation.

From the various conditions above, it is necessary to have the right strategy so that entrepreneurs, especially students, can survive until the Covid-19 pandemic and develop their business further. This study will explore how and why digital business ecosystem is an alternative solutions for students who become entrepreneurs. Moore in Adner mentions that the business ecosystem is an economic community consisting of organizations and individuals who interact with each other in business. This economic community produces goods and services from value for customers, who are members of the ecosystem itself. In this case, the members are suppliers, main producers, competitors, and other stakeholders (Adner, 2016). Golnar mentioned that digital Ecosystems will improve the company's proposition, connecting companies, suppliers, distributors, partners, customers and stakeholders and become the engine that drives performance and delivers strategic impact on the economy (Pooya et al., 2021). Melike explained that the business ecosystem is an important form of collaboration between organizations and a driver of company success (Gueler \& Schneider, 2021). Digital ecosystem can be defined as technology applications that cover innovation and business ecosystem (Gupta et al., 2019). Various types of goods suppliers, sellers and consumers together with aggregators work together to take advantage of the formed business ecosystem. In this ecosystem there are various business activities such as buying and selling between sellers and consumers, suppliers and sellers, etc. In this ecosystem there are activities of collaborating, competing, sharing benefits, etc. In his report, Deloitte explained that the results of a study of 50 cases, there are 4 major groups of forms of business ecosystem models (Amit Sahasrabudhe, 2012). Opinions from previous researchers confirm that an ecosystem business is a necessity in a situation of intense competition and disruption.

The development of Information and Communication Technology (ICT) has changed various business approaches that have been running, especially during the Covid-19 Pandemic. In line with developments in the era of the industrial revolution 4.0, technology and communication play a strategic role, various companies are trying to take advantage of communication technology to win the competition. In several industrial sectors, the Covid-19 pandemic has increasingly encouraged and accelerated business transformation from conventional methods to businesses using communication technology. Deloitte in its report states that the digital economy is increasing faster than the conventional economy (Mehrotra, 2017). The combination of business ecosystem and ICT is a strategy currently used by many entrepreneurs. Research shows that most of the university students have to become e-commerce entrepreneurs in the future (Wildan et al., 2019). Other research, mentions, the availability of e-commerce, encourage someone to become an entrepreneur because of the availability of good internet infrastructure and inexpensive (Bida \& Maryati, 2020). Other research states that E-commerce is a means to start a business, many new business units have sprung up that only have smart phones where transactions can be reached anytime and anywhere (Evita, 2020). In a study conducted on accounting students at the Islamic 
University of Malang, partially e-commerce has a significant effect on decision making for entrepreneurship (Nuris et al., 2021).

The respondents of this study were undergraduate students at Pamulang University in the Management and Accounting study program. Attached are the results of an online survey that is addressed to students and provides responses.

The recent unfavorable condition of the Indonesian economy has had an impact on several things. The Central Statistics Agency in its report in May 2020 stated that the number of unemployed in February 2020 was 6.88 million people and were openly unemployed, of which $5.73 \%$ had a bachelor's degree (Afriyadi, 2020). This is a concern of many parties, including in the university environment. Various universities, both public and private, both majoring in engineering and social humanities, have included entrepreneurship courses to provide students with an understanding of entrepreneurship. The hope is that when they graduate students are no longer looking for work but can create jobs. The topic of entrepreneurship is a topic that is always discussed and researched for various reasons, including entrepreneurship affects the development of a nation and economic growth. Entrepreneurship creates jobs and is the main driver of growth and income, says Filion in (Arcenildo Valderes Da Silva Nunes, 2012).

Many researchers provide a definition of entrepreneurship, among others: According to Zimmerer and Scarborough (2002) entrepreneur is someone who creates a new business by taking the risk of uncertainty in order to achieve profit and growth by identifying opportunities and combining various resources. While Drucker stated that entrepreneurship is the ability to create something new and different (Sudarsih, 2013). Meanwhile, according to Gartner (1988) in Meegawti et al., 2016) defines entrepreneur as the creation of a new organization, and according to Gartner (1989) in (Megawati Simanjuntak, Irma Awwaliyah, Hayati, Rico J Artanto, 2016 ) mentions that there are two lines of thought about the meaning of entrepreneurship. The first definition focuses on themes related to entrepreneurial characteristics, such as innovation, growth, risk, uniqueness, etc. The second addresses issues related to entrepreneurial outcomes in terms of value creation. Why is this research focused on entrepreneurial students: Reynold in (Galina Shirokova at al.,2015) states that student entrepreneurship is defined as any attempt to build a business carried out by one or more students. In the view of strength, entrepreneurial students have the capacity and strength which are the capital in solving business problems, it's just that entrepreneurial students often don't realize it (Yaqien, Raharjo, \& Gutama, 2018). Entrepreneurial students have the opportunity to take advantage of the university's resources. Various activities related to entrepreneurship training that will increase students' knowledge and skills, access to business contacts, and financial networks and resources, are very important to improve the ability to recognize opportunities (Galina Shiokova at al.,2015).

A systematic evaluation of the performance of effective management has become a very important tool for measuring organizational success, especially micro and small businesses which are the source of income for most people (Nunes 2012). The condition of the Covid-19 pandemic in which physical distancing is enforced has affected consumer spending patterns and therefore a strategy is needed to improve business performance. Bond (2007) in (Nunes, 2012), states that organizational performance depends on the integration of all its activities; of the formulation of strategies and actions that contribute to the achievement of the defined goals. Therefore, performance management can change organizational behavior, improve organizational activities and show where problems can arise and why. Business strategy is directed so that a business can have good marketing performance, which will also have an impact on financial performance. In the Covid-19 Pandemic situation, almost all businesses face obstacles in achieving good business performance and therefore there needs to be the right strategy.

Business ecosystem, this terminology is often heard but what is the relationship between 
ecosystem, entrepreneurship and business performance, many entrepreneurs do not understand it. As mentioned in the introduction, this section will discuss ecosystems in more detail. Discussions on ecosystems can be seen from various things such as infrastructure networks, digital ecosystems, components and implementation of an ecosystem and business ecosystem. Marcel stated that an ecosystem is a network consisting of self-interested actors but interdependent and together create value (Marcel et al., 2019). Deloitte (Amit Sahasrabudhe, 2012) in the report classifies ecosystems into four categories and can be broadly grouped into static and dynamic ones. In more detail, it can be seen as follows. : 1) Static, this type of ecosystem focuses on collecting and coordinating various resources, which can add value to the ecosystem organizer (aggregator). 2) Dynamic, this ecosystem seeks to create an environment where components or entrepreneurs in the ecosystem learn faster and work together, so that the resources in the ecosystem continue to grow in value.

In general, an ecosystem is a collection of 3 or more entrepreneurs either in the form of organizations or independent individuals who interact with one another to achieve a common goal. There are 3 assumptions used to explain the meaning of an ecosystem: (1) The purpose of an ecosystem is to improve business performance. (2) Ecosystems consist of organizations or individuals or a combination of both. (3) And the ecosystem is not limited to achieving one particular goal, such as innovation, but also other things.

Discussions about ecosystems are actually familiar because every entrepreneur will certainly be involved in an ecosystem such as with suppliers and customers. Currently, entrepreneurs only focus on ecosystem statics, namely the focus on collecting and coordinating existing resources. This ecosystem does not encourage large value additions. Dynamic ecosystems are the solution, dynamic ecosystems provide opportunities, previously unseen, to accelerate the improvement of the business performance of components or entrepreneurs in the ecosystem.
Often entrepreneurs make fundamental changes to the existing ecosystem to increase the value of their business. Based on a study conducted by Deloitte on 50 cases, which are based on the basic structure, the presence or absence of organizers/ aggregators and the relationship between components/entrepreneurs in the ecosystem, there are 4 types of ecosystems.

The four types of ecosystems are: (1) Centralized; The ecosystem is centralized and there are clear organizers/aggregators, interacting only with entrepreneurs/participants so that the objectives of the ecosystem are achieved. Entrepreneurs/participants generally do not interact with each other. (2) Sequential; This is the pattern most often used in traditional supply chain patterns. Includes a series of activities coordinated by the organizer/aggregator. (3) facilitated; The facilitated ecosystem has a network-like relationship with a complex pattern in which interactions develop among entrepreneurs/participants. (4) Self-organized; A self-regulated and pure ecosystem driven by entrepreneurs/participants without anyone organizing, interconnected with many patterns, entrepreneurs/participants come together and pursue goals together.

Dynamic ecosystems are the bulk of the ecosystems that exist today, focused on combining and coordinating things, be it suppliers, customers or simply ideas. The rapid development of technology and the evolution of the internet have created a wide choice of ecosystem schemes, presenting a significant opportunity to accelerate the improvement of the performance of entrepreneurs/participants, by working together on a larger scale. Dynamic ecosystem is an option because it opens up opportunities for faster business performance improvement of entrepreneurs/participants. This ecosystem is highly scalable and allows for a higher level of interaction between entrepreneurs/participants.

Regarding ecosystems, entrepreneurs in the world respond in various ways, some people view the rise of the ecosystem as an opportunity to create a strong/powerful competitive advantage. In a Deloitte report (Kelly, 2015) stated that in 
July 2014, the CEO of Softbank Japan explained its strategy as follows: "By providing all kinds of services and content on our platform, we aim to create a comprehensive ecosystem that competitors will not be able to do".

There is a relation between the circular economy and business ecosystem, circular economy model can be achieved through collaboration within a business ecosystem. The use of digital technology plays important role in this process, as it provides benefits in building networks among different members (Trevisan et al., 2021). With regard to the business ecosystem, digital industry transformation is currently taking place, which provides an opportunity and necessity for entrepreneurs to grow their business performance. However, not many entrepreneurs are ready to innovate for a new solution and keep up with industry 4.0 developments. A structured and well-managed ecosystem will be a source of competitive advantage for entrepreneurs in meeting diverse customer demands, and providing integrated solutions that make it easier for customers to get what they want faster.

Inevitably, the use of Information and Communication Technology has become a necessity in business. The researcher's experience in exploring to develop a business ecosystem and meeting with several information technology application developers, found a variety of application specifications that can be used ranging from simple to perfect and quite expensive. Advances in digital technology have driven the growth of new collaborative organizational networks such as the digital business ecosystem. This ecosystem is collaborative environment consisting of various entities that together create value through information and communication technology (ICT) (Senyo et al., 2019) Some people call this application a marketplace. Turban in (Khumaidi, 2018) defines that Marketplace is a virtual market where sellers and buyers meet and carry out various types of transactions.

There are 2 types of marketplaces, namely: (1) personal marketplaces; Turban in (Khumaidi, 2018) defines as a marketplace that is owned and operated by a company/individual. Marketplaces like this are better known as E-commerce. Whinston in (Apriadia \& Saputra, 2017) defines e-commerce as a means needed by sellers, consumers to cut service costs to increase service speed and utilize internet technology. Entrepreneurs use e-commerce to expand their marketing reach. This application can be made according to your needs or buy an application that is ready and just used. Supported by good publications will encourage people to visit the e-commerce and shop. Publication must be done by entrepreneurs so that their e-commerce is known by many people who are potential buyers. There are various ways to publish it either using social media such as Instagram, Facebook, Twitter, etc. or take advantage of the concept of SEO (Search Engine Optimization) both organically and non-organically. Owning an e-commerce is not much different from owning a physical store, the difference is that entrepreneurs do not incur building rental costs or building purchase costs and renovation costs. The rest is almost the same, entrepreneurs must continue to carry out activities such as customer service, promotion and marketing, operations to delivery of goods sold, also prepare internet networks and applications for payment gateways. (2) General Marketplace; What distinguishes it from a private marketplace is that in a public marketplace, there are parties who manage and operate the application. as well as the owner of the marketplace. The manager tries to gather as many sellers and buyers as possible to transact through the marketplace. The manager offers various promotions to sellers and buyers such as free shipping, etc. There are many and well-known marketplaces of this type, such as Bukalapak, Tokopedia, Shopee in Indonesia or the well-known alibaba created by Jack Ma. The marketplace managers compete with each other to gather as many sellers and buyers as possible because then the marketplace manager will earn income. Managers offer ease of transaction by setting up payment gateway facilities so that buyers only need to make transfers from mobile banking services held in the account of the marketplace manager, before being transferred to the seller. The combination of the ecosystem concept and 
the use of the right marketplace can be a reliable way to encourage the growth of entrepreneurial students in the campus environment. This is in line with the results of research which states that entrepreneurial students use the marketplace to expand the product market they market (Hidayat, 2021). This is suitable for environmental conditions at Pamulang University, which has 1,768 permanent lecturers and 74,340 registered students (University Profile, 2020).

\section{METHODS}

In the introduction, the researcher mentioned that this research will be carried out using qualitative methods, considering that there have not been many studies that have made students into entrepreneurship at Pamulang University as their research, the research carried out focuses more on motivation, factors of interest in entrepreneurship. In his book John. W Creswell said that data collection is one of the stages in doing (Creswell, 2014) and as an informant are students who are entrepreneurs.

According to Rudi Hartono qualitative research is defined as research that aims to understand a phenomenon that focuses on a general picture rather than dividing it into variables and according to Ari in Hartono qualitative research aims to get a holistic picture of a phenomenon and depth of understanding and not analysis data (Hartono, 2020).

There are various types of qualitative research, but this research uses a case study type. Rudi Hartono in his presentation stated that case studies: (1) It is a type of ethnographic research study that focuses on something, such as one individual, one group, one organization, or one program. (2) Aims to get a detailed explanation and understanding of the phenomenon or "case". (3) Using various methods, such as interviews, observations, and archives to collect data.

Robert explained that case studies are selected when (1) the research question of the research conducted is "how" or "why", (2) the researcher has little or no control over the events/behaviors that occur, and (3) the focus of the research is on phenomena. contemporary and constitutes data a"case" (Yin,2018). In another section it is stated that the case study is an empirical method that investigates current phenomena ("cases") in depth and in real-world contexts, especially where the boundary between phenomenon and context is not too unclear (Yin, 2018).

Research methodology used premises premises as follows: Determination of Research Questions (Research Questions); As mentioned in the introduction, this research has the following research questions. : why does marketing performance during the Covid-19 pandemic tend to decrease and how can the business marketing performance of entrepreneurial students during the Covid-19 pandemic increase? The question arises from conditions on the ground where during the Covid-19 Pandemic many entrepreneurs experienced problems related to their business. On the other hand, some of Pamulang University students also act as entrepreneurs whose income is used, among others, to finance their studies.

Literature review; To complete this research, the researcher conducted a literature review for topics regarding entrepreneurship and students, marketing performance, business ecosystem and marketplace. For the business ecosystem and marketplace, it refers to various sources, especially journals and references from abroad, this is because the discussion about the concept of the business ecosystem and marketplace has not been widely discussed by researchers in Indonesia. Various concepts of ecosystem and marketplace have been discussed by various researchers or applied by entrepreneurs as an effort to improve business performance. The experience of researchers in banking and cooperatives for more than 17 years also has an influence in seeing the problems faced by entrepreneurship students.

Conceptual Framework Development; A conceptual framework was developed for this study and used as the research framework. This framework is based on a discussion of concepts and frameworks and a comparison between the marketing performance improvement strategies used by students and those needed. The concept of a business ecosystem and marketplace has been widely applied in daily business practices 
both in Indonesia and abroad, in order to increase added value for entrepreneurs and utilize the resources that exist in the ecosystem. Through this research, researchers will conduct research on the implementation of business ecosystems and marketplaces in students and universities where the students study.

Case studies and document studies; At this stage the researcher focuses on the study and analysis of the notion of entrepreneurship, the things that become the basis for measuring marketing performance, marketing strategies, implementing various business ecosystem concepts and using the marketplace as a strategy to improve marketing performance with a qualitative approach. Researchers used qualitative data collection methods.

Questionnaire survey; at this stage the survey will be made in a qualitative form with a closed question scheme and multiple choice types. The questionnaire consists of 3 parts, namely (a) the profile of students who are entrepreneurs; contains questions related to, among others, how long students have been studying at Pamulang University, type of business, student background so that they are entrepreneurship, business scale (Micro, Small or Medium) (b) strategies implemented by entrepreneurial students at this time/during the Covid-19 pandemic ; For this purpose, several questions are asked, including: how to introduce their business to the public, their business marketing targets, obstacles faced in developing their business (c) Strategies needed by entrepreneurship students to encourage business marketing performance improvements run by entrepreneurship students; For this matter, questions are asked, including whether the Pamulang University academic community has become the target market and whether the business ecosystem and marketplace are effective tools for product marketing during the Covid-19 pandemic. The survey is made electronically by utilizing the features in the google form and distributed via WAG by providing a link. The purpose of carrying out an online survey is to make the process of filling out questionnaires by respondents/students who are entrepreneurs become easier, the data collection process still adheres to physical distancing and data processing by researchers becomes easier because raw data is available in the form of files that are easy to process with analytical tools/applications. data. Data collection is carried out for 1 month to provide more opportunities for students and researchers target a minimum of 100 student respondents who are entrepreneurs.

Discussion and analysis of results; Data obtained from students were compiled, sorted and analyzed. From the results of the analysis, the current condition of entrepreneurship students at Pamulang University will be illustrated as asked in the questionnaire, the strategies implemented in marketing their products and the things that are hopes for developing their business, especially in the conditions of the Covid-19 pandemic. There is a sorting and analysis based on information regarding: (a) the length of time they have studied at Pamulang University, (b) the ownership of the business being run (owner, reseller or others) (c) The length of time the business has been run (d) the background why students are entrepreneurs (e) ) the scale of the business being run (f) the promotion method currently used (g) what is needed to improve their business performance $(\mathrm{h})$ the opinion of students regarding the use of the business ecosystem and marketplace.

Develop a marketing performance strategy framework; Based on the analysis of the data above, researchers will process and develop a marketing performance improvement strategy based on a business and technology ecosystem based on the widely implemented ecosystem and marketplace concept and combine it with the conditions faced by entrepreneurial students at Pamulang University. Conclusion; The results of this study will be summarized as conclusions and become suggestions.

\section{RESULTS}

Entrepreneurial student profile; contains questions related to, among others, how long students have been studying at Pamulang University, type of business, student background so that they are entrepreneurship, business scale (Micro, Small or Medium). 
Anda saat ini berkuliah di semester berapa ?

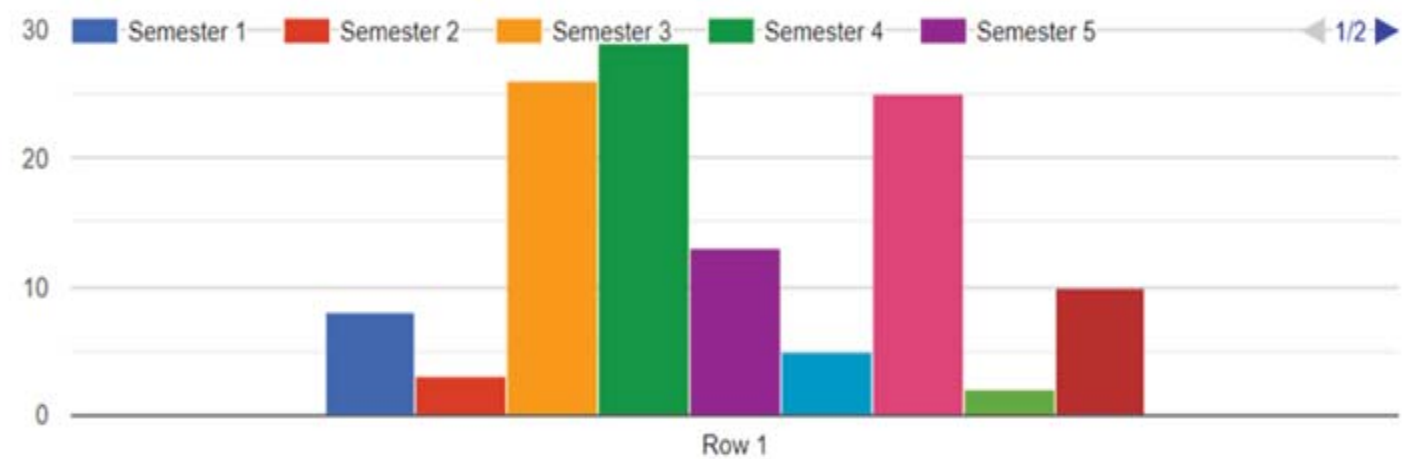

Figure 1. Length of student studying

121 responses

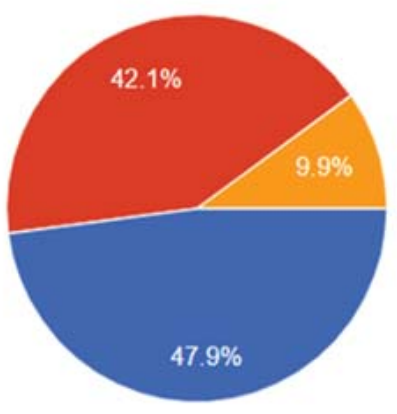

Pemilik produk

- Reseller

- Franchaisee (membeli suatu merek franchise)

Figure 2. Business ownership

121 responses
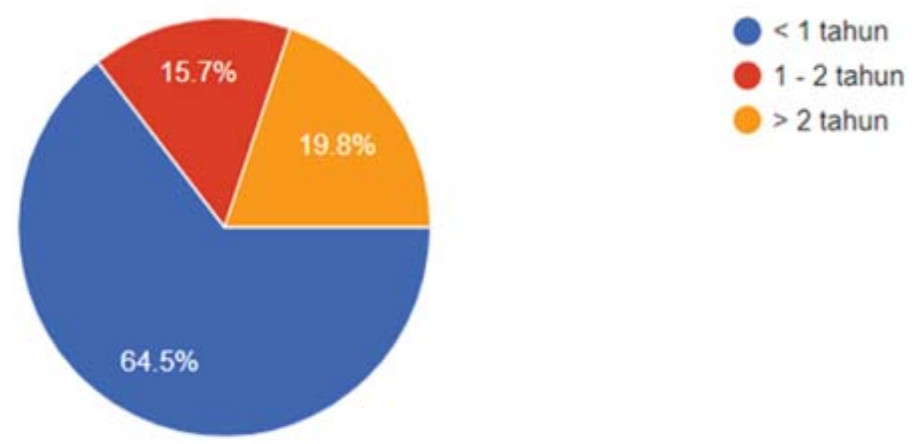

Figure 3. How long does the business run 
121 responses

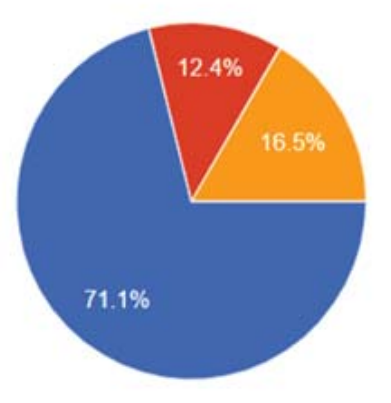

Hobby/memiliki ketrampilan pada bidang usaha yang dijalankan

Melanjutkan usaha keluarga

Mengikuti trend

Figure 4. Background of running a business

121 responses

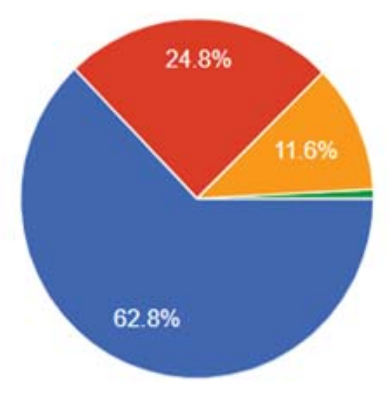

Usaha MIkro (aset maks Rp. $50 \mathrm{Jt}$; omset pertahun s/d Rp. $300 \mathrm{Jt}$ )

Usaha Kecil (aset > Rp. $50 \mathrm{Jt}$ - Rp. 500 $\mathrm{Jt}$; omset pertahun > Rp. 300 Juta s/d Rp. 2,5 Miliar)

Usaha Mlkro (omset pertahun s/d Rp 300 Juta)

- Usaha Kecil (omset pertahun > Rp. 300 Juta s/d Rp. 2,5 Miliar)

Figure 5. Student business scale

121 responses

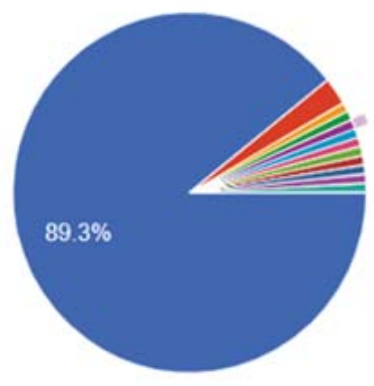

Media sosial (Facebook, instagram dsb.)

- Flyer atau brosur

Dari link teman ke teman

- Tidak, karena target pasar saya adala..

- Menawarkan dari kelas ke kelas karen..

- Sebenarnya saya masih dalam tahap...

- Menjual ke berbagai penjual dan reseller

- Tidak ada

A $1 / 2 \nabla$

Figure 6. How to introduce a product 
121 responses

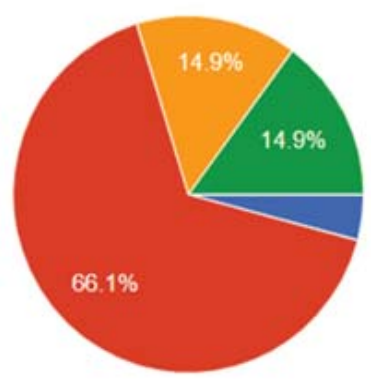

Manajemen

Marketing (digital marketing dsb.)

Pengelolaan keuangan

Operasional (kemasan, perijinan dsb.)

Figure 7. Problems faced by students

121 responses

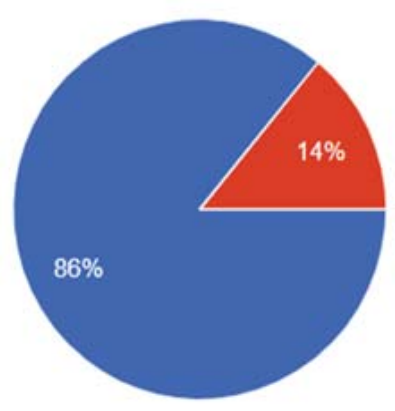

Ya

Tidak

Figure 8. How to introduce products

Strategies run by entrepreneurial students currently/during the Covid-19 pandemic; For this, several questions were asked, including: how to introduce their business to the public, their business marketing targets, the obstacles they faced in developing their business.

Strategies needed by entrepreneurship students to encourage increased business marketing performance run by entrepreneurship students; For this, questions are asked, including whether the academic community of Pamulang University has become a target market and whether the business ecosystem and marketplace are effective tools for product marketing during the Covid-19 pandemic.

\section{DISCUSSION}

Based on the data obtained from the respondents, namely (1) Most of the entrepreneurial students study in semesters 4 and 7. (2) $47.9 \%$ of entrepreneurial students build their own business, not as resellers or continuing the family business. (3) $64.5 \%$ of students who are entrepreneurial have a business that is built for no more than 1 year. (4) $71.1 \%$ of students start a business because students have skills/ hobbies in the business field. (5) $89.3 \%$ of entrepreneurial students use social media as a means to introduce their products (6) $66.1 \%$ of students need digital marketing skills to boost their business performance. 
hardiness, namely the ability to control the life he lives, always think creatively and innovatively in developing his business (Sabela et al., 2015).

Also, the results of research by Sindy Husnul Yaqien et al., on students from Universitas Padjajaran who are entrepreneurs, explain that there are several dimensions such as: resources, options, possibilities, exceptions and solutions in students who play a role in the success of the student's efforts.

Based on the two research results, entrepreneurial students have hardiness and these dimensions include Pamulang University students who are entrepreneurial. there is support from external students. The environment has an equally important role in developing entrepreneurship, and this support comes from the campus, which is implemented in the form of, among others, forming a business ecosystem and using technology. This is as done by several campuses in Indonesia in developing entrepreneurial students or their fostered partners.

In its efforts to increase sales of its fostered partners, IncuBie Institute for Research and Community Service (LPPM) IPB University, not only created an outlet located at Jalan Sukasari I Number 12 A, Bogor, but also launched http://emarket.incubie.ipb ac.id to make it easier for prospective buyers to shop. IPB University has made efforts to prepare a business and technology ecosystem so that it is easier for its fostered partners to develop their businesses, especially those related to marketing.

\section{CONCLUSION}

Based on the data obtained from the respondents, among others: (1) Most of the entrepreneurial students studied in semesters 4 and 7. (2) $47.9 \%$ of entrepreneurial students built their own business, not as resellers or continuing the family business. (3) $64.5 \%$ of students who are entrepreneurial have a business that is built for no more than 1 year. (4) $71.1 \%$ of students start a business because students have skills/ hobbies in the business field. (5) $89.3 \%$ of entrepreneurial students use social media as a means to introduce their products (6) $66.1 \%$ of students need digital marketing skills to boost their business performance.

Based on information and research related to entrepreneurial students, it can be concluded that: (1) In general, Pamulang University students who are entrepreneurial have hardiness attitudes and 5 psychological dimensions, because without this, students will not start entrepreneurship and run until this research is carried out. (2) In the course of their business, students have several limitations, such as the lack of skills and capital needed to develop entrepreneurial students. These skills include management, operations \& production, marketing etc. Their limitations in terms of skills have been partially overcome through the courses given in lectures and trainings that students get from various sources. (3) The skills possessed by students and the current business ecosystem are not sufficient to support the student's business development better and faster. Students rely on their own resources to develop their business, such as utilizing e-commerce, etc. The existence of e-commerce will facilitate entrepreneurs in marketing their products without the need to incur expensive costs in promotion. In addition, entrepreneurs can introduce various products in detail to the public with easy payments method (Istiqomah, 2020). The large market in Pamulang University, which consists of the academic community, cannot be explored more deeply as the target market for entrepreneurial students. (4) Facing the limitations that students have, the role of external parties is important, the role as a facilitator in forming a business ecosystem and using technology, as shown in the following figure below. Increasing level of competition at this time, it is necessary to change the strategy to be able to reach the market with previously focused on product-oriented and consumer-oriented into business ecosystem-oriented (Lucky et al., 2019). 


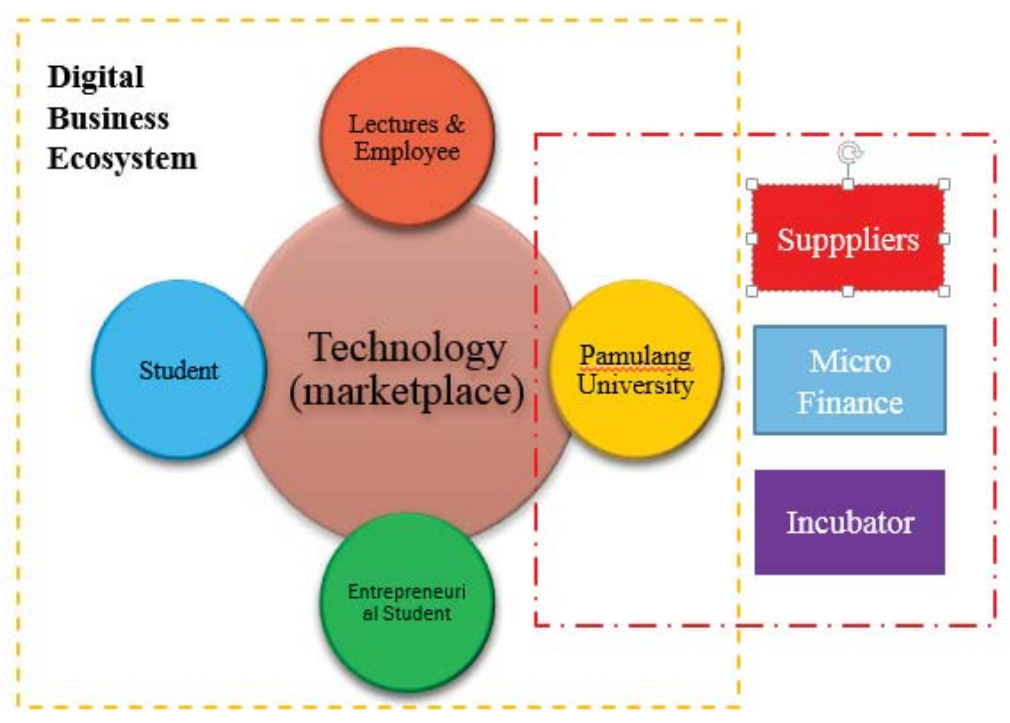

Figure 8. How to introduce products

There are 3 dimensions of university support factors, two of them are perceived concept development support : the university facilitates every entrepreneurial student to relate to each other and the university acts as a key for students starting new businesses (Qausar \& Megawati, 2019). Universities have an important role in the development of entrepreneurship and are not limited to motivating students.

In this case, Pamulang University facilitates a business and technology ecosystem to bridge transactions that occur between entrepreneurial students and the academic community. The business ecosystem is prepared to support student business growth both in financial and nonfinancial terms, while technology, in this case the marketplace, is a technology/application that can connect entrepreneurial students with potential buyers, in this case the academic community of Pamulang University. This is in line with research which states that a business ecosystem is an economic community based on interactions between organizations and individuals (organisms in the business world). The ecosystem does not only include the main business (core business) and company development, but also includes stakeholders such as associations industry, government and investors (Edhie et al., 2021). $\mathrm{Ke}$ Rong in his research said that the concept of a business ecosystem is a development of supply chain network theory, which includes other organizations such as universities, industry associations and other stakeholders, and their interactions (Rong et al., 2015). The digital business ecosystem becomes a necessity, is digital technology consisting of buyers, sellers, suppliers interacting with each other using technology to facilitate business activities (Taufik \& Rohmah, 2015). The application is also a bridge with other parties such as financial institutions, incubators, etc. Business activities related to student sales transactions can be stored and can be utilized by the related parties. Other research states that a business ecosystem is an economic community supported by organizations and individuals who interact with each other, producing goods and services of value to customers, who are members of the ecosystem itself (Awano \& Tsujimoto, 2021).

\section{ACKNOWLEDGEMENT}

The greatest appreciation is given to the students of the Faculty of Economics, Pamulang University who have taken the time to fill out this 
questionnaire and the lecturers at the Management Study Program, Faculty of Economics, Pamulang University who have helped so that this questionnaire can be distributed to students.

\section{REFERENCES}

Adner, R. (2016). Ecosystem as Structure: An Actionable Construct for Strategy. Https:// Doi.Org/10.1177/0149206316678451，43(1), 39-58. https://doi.org/10.1177/01492063166 78451.

Amit Sahasrabudhe, H. J. (2012). Performance ecosystem A decision framework to take performance to the next level. Deloitte University.

Apriadia, D., \& Saputra, A. Y. (2017). Marketplace-Based E-Commerce in an Effort to Shorten Sales Distribution of Agricultural Products. JOURNAL RESTI Vo. 1 No. 2 , 131-136.

Arcenildo Valderes Da Silva Nunes, E. D. (2012). The use of performance indicators for small and micro enterprises (SMEs): A Brazilian regional experience. African Journal of Business Management Vol. 6 (28), 8378-8389.

Awano, H., \& Tsujimoto, M. (2021). The Mechanisms for Business Ecosystem Members to Capture Part of a Business Ecosystem's Joint Created Value. https://doi.org/10.3390/ su13084573Afriyadi, A. D. (2020). Seconds Finance. Taken back from Detik.com: https:// finance.detik.com/berita-ekonomi-bisnis/d5003020/68-juta-orang-indonesia-nganggurpaling-banyak-lulusan-smk.

Bida, S., \& Maryati, R. (2020). Pengaruh Lingkungan, Pendidikan Wewirausahaan dan Penggunaan E-commerce pada Peningkatan Minat Berwirausaha Mahasiswa FEB UPI YAI. IKRA-ITH EKONOMIKA YAI, 3(2). http://repository.upi-yai.ac.id/1635/.

College Profile. (2020). Taken back from https:// pddikti.kemdikbud.go.id/:https://pddikti. kemdikbud.go.id/data_pt/

Creswell, J. W. (2014). Research Design : Qualitative, Quantitative and Mixed Method Approaches. California: SAGE Publications, Inc.
Edhie, B. Y., Siregar, H., Azam, A. A., \& Tony, I. (2021). Model Ekosistem Bisnis Pariwisata Terpadu Berbasis Strategi 5 Jalur. INOVASI Jurnal Politik Dan Kebijakan, 18(1). http:// jurnal.balitbang.sumutprov.go.id/index.php/ inovasi/article/view/309.

Evita, T. W. (2020). E-commerce dan Sistem Informasi Akuntansi sebagai Faktor Pendorong Pengambilan Keputusan Mahasiswa Akuntansi untuk Berwirausaha. E-JRA, 9(3). http://www.riset.unisma.ac.id/index.php/jra/ article/view/6144.

Galina Shirokova; Oleksiy Osiyevsky; Karina Bogatyreva . (2015). Exploring the intentione behavior link in student entrepreneurship: Moderating effects of individual and environmental characteristics. European Management Journal.

Gueler, M. S., \& Schneider, S. (2021). The resource-based view in business ecosystems: A perspective on the determinants of a valuable resource and capability. Journal of Business Research, 133, 158-169. https://doi. org/10.1016/J.JBUSRES.2021.04.061.

Gupta, R., Mejia, C., \& Kajikawa, Y. (2019). Business, innovation and digital ecosystems landscape survey and knowledge cross sharing. Technological Forecasting and Social Change, 147, 100-109. https://doi.org/10.1016/J. TECHFORE.2019.07.004.

Hartono, R. (2020). Careful Tips to Become a Great Qualitative Researcher. Virtual Coaching Clinic 3. South Tangerang, Banten: Pamulang University.

Helmi, A. F. (2011). Determinant Model of Innovative Behavior in Students. Journal of Psychology volume 38, NO. 2, 134 - 146.

Hidayat, A. S. (2021). DSpace Home. Retrieved from https://dspace.uii.ac.id/ handle/123456789/7163.

Indonesian Student Entrepreneurship Program. (2020). Taken back from https://simpkmi.kemdikbud.go.id: https://sim-pkmi. kemdikbud.go.id/portal/.

Info-Science-Dikti. (2017). Taken back from the Ministry of Research and Technology: https:// www.ristekbrin.go.id/info-iptek-dikti/push- 
mahasiswa-jadi-wirausaha/.

Isanawikrama. (2019). Binus Entrepreneurship Center. Taken back from binus.ac.id:https:// binus.ac.id/entrepreneur/2019/10/22/perangovernment-dalam-kewirausa-haan/.

Istiqomah. (2020). Pemanfaatan E-commerce terhadap Minat Berwirausaha Mahasiswa Akademi Kesejahteraan AKK Yogyakarta. Jurnal Socia Akademika, 6(2). https://aksakk.e-journal.id/jsa/article/view/99.

Kelly, E. (2015). Business Ecosystems Come of Age. Deloitte University Press.

Khumaidi, A. (2018). Designing a Smart Shirt Order Marketplace Application Using a Responsive Web to Make it Easy for Customers to Design according to their taste. Ikraith-Informatics Vo. 2, No. 2, 61-69.

Loviana, M. (2017). Analysis of Entrepreneurial Motivation Factors for BusinessAdministration Students Class of 2013. E-Proceeding of Management Telkom University, 909. https:// openlibrarypublications.telkomuniversity. ac.id/index.php/management/article/ view/4650/440.

Lucky, N., Wiwik, U., \& Meiwanto Doktoralina, C. (2019). Ekosistem Bisnis Wisata Halal dalam Perspektif Maqasid Syariah (Halal Tourism Business Ecosystem in the Maqasid Syariah Perspective). Perisai : Islamic Banking and Finance Journal, 3(2). http://ojs.umsida. ac.id/index.php/perisai/article/view/84.

Marcel, B., Jonathan, S., \& Joel, W. (2019). What Is an Ecosystem? Incorporating 25 Years of Ecosystem Research. Academy of Management Proceedings. https://papers.ssrn. com/sol3/papers.cfm?abstract_id=3437014.

Megawati Simanjuntak, Irma Awwaliyah, Hayati, Rico J Artanto. (2016). The Entrepreneurial Potential among Undergraduate Students. Journal of Business \& Management, 2016, Vol. XVII, No. 2, 75-84, 75-84.

Mehrotra, M. (2017). Accelerating Digital Ecosystem Development through Strategic Alliances. Deloitte monitors.

Ministry of Education and Culture. (2021). Higher Education Database. Retrieved from https://pddikti.kemdikbud.go.id/data_pt/.
MSME data (2019).. Jakarta: Ministry of Cooperatives and SMEs.

Nuris, S., Moh., A., \& Afifudin. (2021). Pengaruh E-commerce dan E-bussines dalam Pengambilan Keputusan untuk Berwirausaha pada Kalangan Mahasiswa FEB Unisma. Jurnal Ilmiah Riset Akuntansi, 10(2). http:// www.riset.unisma.ac.id/index.php/jra/article/ view/12988.

Osi Isna Sabela, J. A. (2014). Entrepreneurial Student Resilience:. Journal of Psychology Undip Vol.13 No.2, 170-189.

Pakpahan, A. K. (2020). Covid-19 and Implications for Micro, Small and Medium Enterprises. Scientific Journal of International Relations Parahyangan University, 59-64.

Pooya, G., Cheng, N., Marshall, A., Dencik, J., \& Agrawal, N. (2021). Business success in the platform economy depends on the right ecosystem strategy and execution. Strategy \&amp; Leadership, ahead-of-p(ahead-ofprint). https://doi.org/10.1108/SL-07-20210076.

Qausar, G. R., \& Megawati. (2019). Pengaruh Faktor Dukungan Universitas dan Kepribadian Proaktif terhadap Intensi Berwirausaha pada Mahasiswa S1 Fakultas Ekonomi dan Bisnis Universitas Syiah Kuala. Jurnal Ilmiah Mahasiswa Ekonomi Manajemen, 4(1), 157-171. https://doi.org/10.24815/JIMEN. V4I1.10019.

Rahardjo, M. (2017). Case Study Research Design. Malang, East Java: UIN Maulana Malik Ibrahim.

Rahardjo, M. (2017). Research Repository. Taken back from repository.uin-malang.ac.id/: http:// repository. uin-malang.ac.id/1104/.

Rahman Faisal, L. A. (2020). Determinants of Student Entrepreneurial Success in South Tangerang City. Journal of Competitive Marketing Vol 4, No 1.

Rong, K., Hu, G., Lin, Y., Shi, Y., \& Guo, L. (2015). Understanding business ecosystem using a $6 \mathrm{C}$ framework in Internet-of-Thingsbased sectors. International Journal of Production Economics, 159, 41-55. https:// doi.org/10.1016/J.IJPE.2014.09.003. 
Simanjuntak, M., Awwaliyah, I., Hayati, H., \& Artanto, R. J. (2016). The Entrepreneurial Potential among Undergraduate Students. Jurnal Bisnis Dan Manajemen, 17(2), 75-84. https://doi.org/10.24198/JBM.V17I2.29.

Sudarsih, E. (2013). Technopreneurship Education: Increasing the Innovation Power of Engineering Students in Business. Proceedings of the National Conference "Innovation and Technopreneurship" (pp. 55-63). Bogor: Department of Agricultural Industrial Technology, IPB.

Taufik, D., \& Rohmah, L. (2015). An analysis and design of responsive supply chain for pineapple multi products SME based on Digital Business Ecosystem (DBE). Industrial Engineering and Service Science, 155 - 162. https://www.sciencedirect.com/science/
article/pii/S2351978915011427.

Trevisan, A. H., Zacharias, I. S., Castro, C. G., \& Mascarenhas, J. (2021). Circular economy actions in business ecosystems driven by digital technologies. Procedia CIRP, 100, 325-330. https://doi.org/10.1016/J. PROCIR.2021.05.074.

Trihudiyatmanto. (2019). Membangun Minat Berwirausaha Mahasiswa dengan Pengaruh Faktor E-Commerce, Pengetahuan Kewirausahaan dan Gender. PPKM, 6(2), 93 103. http://www.riset.unisma.ac.id/index.php/ jra/article/view/6144.

Wildan, F. T., Mumu, K., \& Tatang, P. (2019). Studi Eksplorasi Minat Berwirausaha E-commerce MahasiswaD3 Teknik Mesin. Journal of Mechanical Engineering Education, 6(1). https://ejournal.upi. edu/index.php/jmee/article/view/18254. 